\title{
Nothing is even more expensive
}

\section{The international Atomic Energy Agency (celebrating its 25th anniversary) has a tenable niche on nuclear power but it is not the only custodian of peace.}

The outlook for the international nuclear power business seems to have improved a little at last week's meeting of the board of governors of the International Atomic Energy Agency (IAEA) at Vienna. That, at least, is what the public noises mean. For one thing, the authority has been able to spell out in its annual budget a prospectus for a much more meticulous procedure for accounting for fissile material ostensibly under international safeguards that might be used for making bombs. For another, in spite of the deteriorating economics of nuclear power enterprises in countries such as the United States, the economic outlook in countries such as West Germany is not nearly as parlous even with a change of government in the of fing. And then the authority had the wit to put up Dr Sigvard Eklund, its director-general until last year, to make the keynote speech at its annual public meeting this week on experience with nuclear power and to echo the late Homi Bhabha in saying "No energy is more expensive than no energy". That message will be remembered.

At the same time, the recognition that countries differ enormously among themselves in their assessment of the importance of nuclear power will begin to sink in. With hindsight, it is entirely credible that, in the United States, the nuclear power industry should have been made uneconomic by the public protests (on the grounds of amenity and safety) of people who are broadly speaking assured of electricity supplies at reasonable cost from conventional fuel sources. In fuel-importing countries such as left-wing France, it is understandable that the balance should lie the other way - and that it should be exaggerated by $M$. Chevenement's enthusiasm for the future. It is more of a surprise that Mr Helmut Schmidt's chancellorship should have been brought to an end partly on the issue of nuclear power, when West Germany is more dependent on imported fuel than most other European countries except Denmark and Sweden.

The truth, of course, is that the nuclear issue in West Germany springs not from the federal republic's need of energy of some kind (on the grounds that no energy would cost more) but from Mr Schmidt's advocacy of President Carter's fleeting belief that there should be neutron bombs in West Germany. Paradoxically, Mr Schmidt's opponents on the nuclear issue, the wayward "Greens", may be more willing to toe the line when the Christian Democrats are in office. The conventional but cynical wisdom that it takes a left-wing government to accomplish right-wing goals (and the other way round) is undermined by the way in which the expectations of those who oppose the policies of their own governments diminish when their governments are replaced. In the end, what will matter is that the countries most in need of nuclear power (and able to afford it) will build nuclear power stations (and, given their need, will be able to do so cheaply); the others will wait.

The problem for the International Atomic Energy Agency that should occupy its new director, Mr Hans Blix, is therefore what has occupied him in his short tenure of his post - how to arrange that countries buying fissile material from others do not use it for making nuclear weapons or, by threatening to do so, disturb the peace. Outwardly, he must be seen to worry. But the nations most often canvassed as the leading members of the next nuclear generation, Israel for example, live so dangerously already that they are more likely to be constrained by conventional diplomacy than by anything a United Nations agency could accomplish (witness this week's withdrawal from West Beirut). The trick, for the next year or so, must be to repeat the demonstration in the past year that international safeguards function effectively while showing that they are consistent with, for example, the reprocessing of spent fuel. Mr Blix appears to have the spirit even for that enterprise.

\section{Health service sickness}

\section{The British government is heading for a row on nationalized medicine; it should reorganize.}

The British National Health Service, variously regarded as a triumph of social engineering and as an embodiment of "socialized medicine", is in trouble. The underlying problems are financial. Since the creation of the health service in 1948, the assumption that the cost of medical care should be a charge on public funds has increasingly been challenged by the disappointing growth of the British economy and by the rapid increase (in real terms) of the cost of medical care, itself a measure of the advance of medical technology. The cost of the National Health Service, $£ 14,500$ million in $1982-83$, is roughly six per cent of the Gross Domestic Product and has increased by some 5 per cent (in real terms) since 1979-80. While the total cost is less than the proportion of national income spent on health care in, for example, West Germany and the United States, successive British governments of all colours have been increasingly perplexed to know how to pay the bills wished on them three decades ago. Although they have differed in their generosity towards the National Health Service, they seem all to have agreed that the salaries paid to those working in it should be kept as low as possible. The consequences have now caught up with Mrs Thatcher's government.

After decades of parsimony, many health service workers are now paid much less than they would be paid in comparable jobs elsewhere. That trainee nurses earn less than they would be paid if they were unemployed is a relic of the days when nursing was considered a kind of extension of voluntary social work, but the nurses are no longer the genteel profession they once were, and have formally rejected, as would have a trades union, this year's offer of a 7.5 per cent salary increase. Those nurses belonging to the Royal College of Nurses (perhaps 60 per cent of all student and qualified nurses) were prevented by their charter from joining this week's one-day strike by other health service workers. The possibility that the self-denying ordinance may be removed from their charter is, however, a sign that gentility has gone for good. (The decision of the Trades Union Congress to urge that other trades unionists should strike in sympathy for at least an hour is, by contrast, more probably a sign of its eagerness to test the effectiveness of the legislation that makes secondary strikes illegal, and those engaging in them susceptible to civil actions by their employers.) So British governments must steel themselves for annual confrontations over health service pay, for there is no prospect of paying proper salaries to those most deprived while keeping the total cost of the National Health Service commensurate with the likely growth of the British economy. But such a state of affairs could not continue for long without damaging the capacity of the health services to care for the sick; 